


\section{DEMETRIOS - PRIZE 2018}

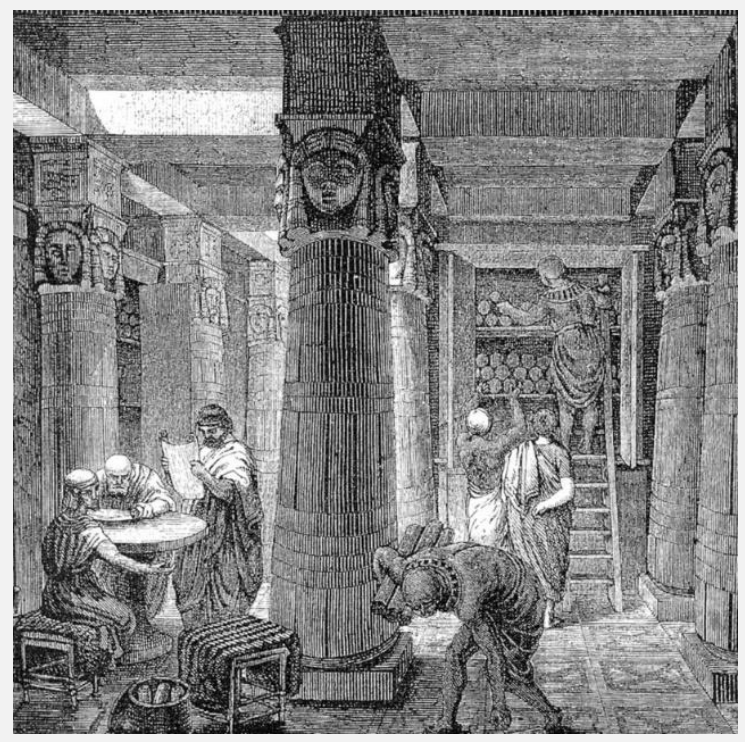

The JOSHA Team is very pleased to share with you information about the IASHA Demetrios Prize 2018.

For the categories BACHELOR, MASTER and DOCTORAL thesis the International Academy of Science, Humanities and Arts (IASHA e.V.) supported by the Biothera Foundation will select 3 theses in each category and award a prize of $€ 500$ each. Our editors will select the winners. The manuscripts of the winners will be published in the Journal of Science, Humanities, and Arts - JOSHA, with a unique DOI for each paper. Theses in either GERMAN or ENGLISH may be submitted. Bachelor, Master, and doctoral theses should be submitted by mail to admin@josha-archive.org.until June 15, 2018.

You will be notified about the winners by August 15. The winners will receive their prize money and their diplomas in a festive act on October 16 . Any questions, do not hesitate to contact us at admin@josha-archive.org Good luck and enjoy!

The "Journal of Science, Humanities and Arts - JOSHA" has been initiated to create a novel internet platform to access the broad diversity of important discoveries and creativity in the fields of Science, Humanities and Arts. At JOSHA we believe, that "Knowledge that is not communicated is wasted knowledge." 


\section{DEMETRIOS - PREIS 2018}

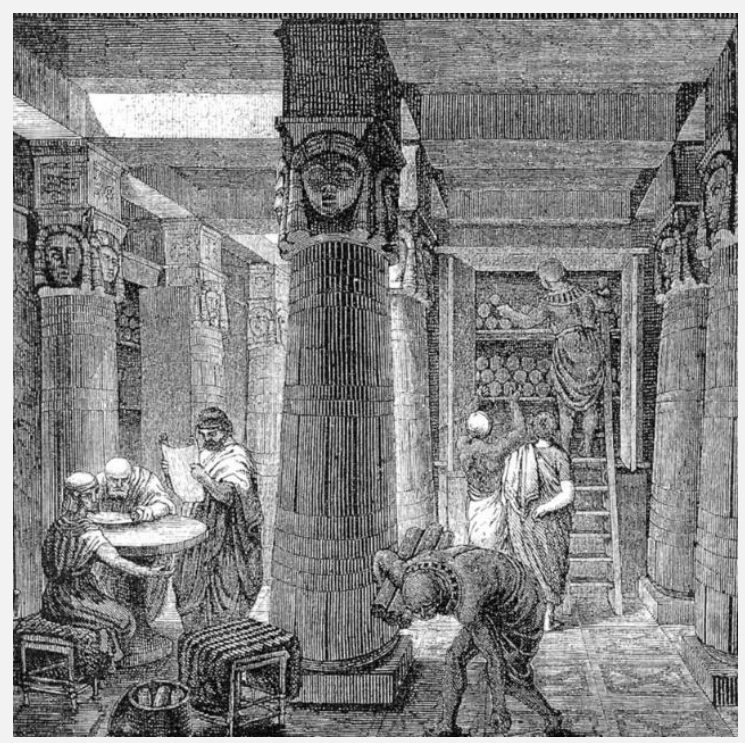

Möchtest Du Deine Abschlussarbeit im JOSHA JOURNAL publizieren?

JOSHA als Open Access Library, die Naturwissenschaftlern, Geisteswissenschaftlern und Künstlern in allen Ländern in allen Sprachen zur Verfügung steht, ist stolz darauf, Ihnen den Demeterios - Preis vorstellen zu dürfen.

Für die Kategorien BACHELOR-, MASTER- und DOKTORArbeiten wird die International Academy of Science, Humanities and Arts (IASHA e.V.) mit Unterstützung der Biothera Stiftung jeweils 3 Preise in Höhe von 500 Euro vergeben. Unsere Editoren werden die Auswahl treffen und die Arbeiten der Gewinner werden mit eigener DOI Nummer in der online Zeitschrift publiziert!

Bachelor-, Master- und Doktor-Arbeiten könnt Ihr uns ab sofort an admin@josha-archive.org zukommen lassen.

Bewerbungsfrist bis 15. Juni 2018

Das JOSHA-Team freut sich sehr auf Eure Bewerbungen! 